\title{
Faktor-faktor yang mempengaruhi motivasi konsumen memilih makanan organik di restaurant sari organik ubud bali
}

\author{
Michell Layendra ${ }^{1)}$ Anak Agung Putri Sri ${ }^{2}$ I Nyoman Tri Sutaguna ${ }^{3)}$ \\ DIV Pariwisata, Fakultas Pariwisata, Universitas udayana ${ }^{123)}$ \\ Jl. DR. R. Goris No. 7 Denpasar, Telp / Fax (0361) 223798 \\ Email : michell.layendra@gmail.com
}

\begin{abstract}
Abstrak
Di Ubud dewasa ini dapat dilihat bahwa restoran organik pun ramai didatangi oleh pengunjung, hal tersebut dapat diartikan bahwa banyak pengunjung yang menaruh minat dalam mengk onsumsi makanan orga nik walaupun di zaman sekarang ini makanan cepat saji lebih mudah dijumpai. Tujuan penelitian ini dilakukan untuk mengetahui faktor yang mempengaruhi dan faktor domin an yang motivasi konsumen memilih makanan organik di restaurant Sari Organik Ubud Bali. Teknik accidental sampling digunakan dengan membagikan kuesioner kepada 100 konsumen yang berkunjung ke restaurant tersebut. Teknik pengumpulan data berupa observasi, kuesioner, wawancara tidak berstruktur, studi pustaka, dan dokumentasi. Teknis analisis faktor dengan menghitung korelasi indikator, ekstraksi faktor, rotasi faktor dan interprestasi faktor dengan bantuan software SPSS version 16.0 for windows. Hasil penelitian menunjukan bahwa hasil analisis faktor terdapat 10 indikator yang di analisis. Dari hasil analisis faktor tersebut terdapat 2 faktor yang terbentuk yang dapat menjelaskan 55,270\% dari total varians yang ada. Dari kedua faktor yang terbentuk adalah faktor pertama yaitu Harga dan faktor yang kedua yaitu Produk. Faktor dominan yang mempengaruhi motivasi konsumen memilih makanan organik di restaurant Sari Organik Ubud Bali adalah faktor Produk dengan total korelasi 2,255 melebihi faktor Harga yaitu 1,500. Jadi dapat disimpulkan bahwa faktor Produk dapat mempengaruhi konsumen dalam memilih makanan organik.
\end{abstract}

Kata kunci: Faktor, Motivasi Konsumen, Makanan Organik

\begin{abstract}
In Ubud these dayit can be seen that even organic restaurants arecrowded with visitors, it can be interpreted that manyvisitors are interested in consuming organic foodeven though these day fast food is easier to find. The purpose of this research was conducted to determine the influence factors of motivation and the dominantfactors that motivate consumers to choose organic food in the Sari Organic restaurant in UbudBali. Accidental sampling technique was used by distributing questionnaires to 100 consumers who visited the restaurant. Data collection techniques such as observation, questionnaires, unstructured interviews, literature study, and documentation. Technical analysis offactors by calculating the indicator correlation, factor extraction, factor rotation and factor interpretation with the helped by SPSS softwareversion 16.0 for windows. The results showed that the results of the factor analysis there are 10 indicators after analyzed. From the results of the analysis of these factors, there are 2 factors formed that can explain 55,270\% of the totalvariance available. Of the two factors formed is thefirst factor is Priceand the secondfactor is Product. The dominant factor influencing the motivation of consumers to choose organic food at Sari Organik restaurant in Ubud Bali restaurant is the Product factor with a total correlation of 2,255 exceeding the Price factor of 1,500. So it can be concluded that the product factor can influence consumers in choosing organic foods.
\end{abstract}

Keywords: Factors, Consumer Motivation, Organic Food

\section{PENDAHULUAN}

Indonesia merupakan negara kepulauan terbesar di dunia yang pada setiap pulaunya memiliki budaya, adat, dan ciri khas nya masing-masing dan sangat beragam. Mulai dari Sabang sampai Merauke, Salah satu pulau di Indonesia yang paling populer adalah Pulau Bali merupakan destinasi wisata paling popular di Indonesia, bahkan dunia internasional pun mengakuinya yaitu Pulau Bali. Pulau Bali merupakan tempat destinasi pariwisata yang banyak dikunjungi oleh para wisatawan 
nusantara maupun mancanegara. Berbagai daya tarik wisata, kuliner, budaya, bangunan, dan segala aspek dimiliki oleh pulau Bali. Maka tidak heran, jika Bali dijadikan sebagai salah satu tujuan atau destinasi wisatawan nusantara hingga mancanegara.

Tabel 1.1 Jumlah Kunjungan Wisatawan ke Provinsi Bali Tahun 2013-2018

\begin{tabular}{|c|c|c|c|c|}
\hline \multirow{2}{*}{ Tahun } & \multicolumn{2}{|c|}{ Jumlah Wisatawan } & \multirow{2}{*}{$\begin{array}{c}\text { Total Wisatawan } \\
\text { (Orang) }\end{array}$} & $\begin{array}{c}\text { Pertumbuhan } \\
(\%)\end{array}$ \\
\cline { 2 - 3 } & $\begin{array}{c}\text { Nusantara } \\
\text { (Orang) }\end{array}$ & $\begin{array}{c}\text { Mancanegara } \\
\text { (Orang) }\end{array}$ & 10.255 .134 & - \\
\hline 2013 & 6.976 .536 & 3.278 .598 & 10.160 .945 & $(0,91)$ \\
\hline 2014 & 6.394 .307 & 3.766 .638 & 11.148 .935 & 9,72 \\
\hline 2015 & 7.147 .100 & 4.001 .835 & 13.571 .617 & 21,73 \\
\hline 2016 & 8.643 .680 & 4.927 .937 & 14.433 .372 & 6,34 \\
\hline 2017 & 8.735 .633 & 5.697 .739 & 15.828 .464 & 9,66 \\
\hline 2018 & 9.757 .991 & 6.070 .473 & & \\
\hline
\end{tabular}

Sumber : Badan Pusat Statistik Provinsi Bali, 2019

Berdasarkan Tabel 1.1 dapat diketahui bahwa jumlah kunjungan wisatawan mancanegara dan nusantara ke Provinsi Bali terjadi peningkatan setiap tahunnya. Data tersebut menunjukkan bahwa Bali masih menjadi daya tarik wisata utama bagi para wisatawan baik nusantara maupun mancanegara. Daya tarik tersebut dapat dilihat berdasarkan tiga hal yang menjadikan Pariwisata di Bali unggul, yang pertama yaitu keunggulan alamnya. Bali yang dianugerahi alam yang sangat indah dan bervariatif. Mulai dari keindahan alam pantai, bawah laut, gunung, danau, sungai, dan hutan dapat ditemukan di Bali. Keberadaan semua keindahan alam yang sangat bervariatif tersebut, sangat berpotensial untuk dijadikan daya tarik wisata. Daya tarik yang kedua yaitu budaya. Masyarakat Bali yang masih menjunjung tinggi budaya berdasarkan agama Hindu, menjadikan hal tersebut juga menjadi daya tarik tersendiri bagi pariwisata Bali. Kebudayaan tersebut dapat tercermin melalui adat istiadat masyarakat, ritual agama Hindu Bali, hingga bangunan khas Bali. Daya tarik yang ketiga yaitu sarana dan prasarana pariwisata, yaitu seperti hotel, restaurant, pusat souvenir, dan lain-lain. Banyaknya daya tarik wisata yang menarik banyak kunjungan wisatawan, menjadikan lengkapnya dan banyaknya sarana dan prasarana pariwisata di Bali yang tersebar di berbagai destinasi wisatanya. Daerah yang ramai dikunjungi wisatawan ketika berkunjung ke Bali diantaranya adalah Kuta, Seminyak, Nusa Dua, dan Ubud.

Ubud terdapat di Kabupaten Gianyar dan dikenal sebagai tempat yang masih asri dan tenang sehingga banyak wisatawan asing memilih untuk menginap dan mengunjungi daerah Ubud dibandingkan wilayah lain. Selain keindahan alam, Ubud juga terkenal akan kesenian, tempat untuk melakukan yoga, serta makanannya.

Tabel 1.2. Jumlah Kunjungan Wisatawan ke Kecamatan Ubud Tahun 2013-2017

\begin{tabular}{|c|c|c|c|c|}
\hline \multirow{2}{*}{ Tahun } & \multicolumn{2}{|c|}{ Jumlah Wisatawan (Orang) } & \multirow{2}{*}{$\begin{array}{c}\text { Total Wisatawan } \\
\text { (Orang) }\end{array}$} & Pertumbuhan (\%) \\
\cline { 2 - 3 } & Nusantara & Mancanegara & 192.215 & - \\
\hline 2013 & 33.885 & 158.330 & 213.912 & 10,14 \\
\hline 2014 & 42.809 & 171.103 & 199.532 & $(7,21)$ \\
\hline 2015 & 33.769 & 165.763 & 873.103 & 33,75 \\
\hline 2016 & 32.545 & 840.558 & 1.523 .983 & 42,70 \\
\hline 2017 & 26.796 & 1.497 .187 & 3.002 .745 & 79,38 \\
\hline
\end{tabular}

Sumber: Dinas Pariwisata Kabupaten Gianyar, 2018

Berdasarkan artikel yang ditulis oleh Mariska Tracy pada tanggal 15 September 2018 dan di publikasi di Pegipegi.com artikel tersebut berjudul "10 Kedai dengan Makanan Organik dan Fresh di Ubud, Bali". Restaurant Sari Organik mendapatkan peringkat pertama dari 10 restaurant yang ada di Ubud. Suasana di restaurant Sari Organik yang berada di jalan Subak Sok Wayah, 
Tjampuhan disebut sebagai tempat yang cocok untuk relaxing, bersantai, baca buku, ngobrol, dan lain-lain sambil menikmati pemandangan sawah yang indah. Restaurant menawarkan buah-buahan dan sayuran yang ditanam sendiri. Bahkan pengunjung bisa memetik sayuran sendiri untuk salad yang akan dimakan. Menu makanan sehat yang ditawarkan antara lain Fruit Salad berkisar Rp 30 ribu, Bodag Omelet berkisar Rp 53 ribu, Pumpkin Soup berkisar Rp 33 ribu, dan lain-lain.

Selain membaca pada website diinternet, biasanya para wisatawan yang akan berkunjung ke suatu tempat juga akan berusaha mendapatkan informasi atau tanggapan dari orang lain yang sudah memiliki pengalaman yang dalam hal ini adalah sudah pernah memiliki pengalaman berkunjung ke suatu tempat atau destinasi, hal ini dilakukan agar timbul keyakinan untuk mengunjungi tempat tersebut. Adapun sumber ulasan yang saat ini sering digunakan oleh pengguna internet yaitu TripAdvisor.com.

Berdasarkan artikel yang ditulis oleh Bagus Ramadhan pada tanggal 19 Juli 2019 dan dipublikasikan di Kulawarga.id, artikel tersebut berjudul "Sistem Review TripAdvisor yang Mengubah Dunia Traveling". Dimana artikel tersebut mengutarakan bahwa TripAdvisor merupakan tarik ulur antara review positif dengan negatif inilah yang kemudian menjadi reputasi dan situs ini berhasil menjadi wadah untuk ulasan berbagai usaha dibidang travel. Lewat ulasanulasan yang terkumpul, TripAdvisor seakan menjadi entitas yang kemudian juga turut memberikan prestise melalui rating (peringkat) dan daftar-daftar terbaik yang rutin mereka buat. Berikut merupakan daftar restaurant di Ubud yang menyajikan makanan organik dapat dilihat pada Tabel 1.3 .

Tabel 1.3. Most Reviewed Restaurant Organik di Kecamatan Ubud, Gianyar Bali

\begin{tabular}{|c|l|l|c|}
\hline No. & \multicolumn{1}{|c|}{ Nama Restaurant } & \multicolumn{1}{|c|}{ Alamat } & Ulasan \\
\hline 1. & Sari Organik & Jl. Raya Tjampuhan, Ubud & 1.766 \\
\hline 2. & Yuya Organic Warung & Jl. Subak Ume Sok Wayah, Ubud & 168 \\
\hline 3. & Abe Do & J1 Tirta Tawar No. 43, Ubud & 334 \\
\hline 4. & Kuyun Restaurant \& Longue & Jl. Raya Mas 47, Ubud & 205 \\
\hline 5. & Ubud Float Garden & Jl. Raya Pejang Kawan, Ubud & 327 \\
\hline 6. & Seasoned & Jl. Raya Pengosekan, Ubud & 411 \\
\hline 7. & Bali Buda & J1 Jembawan no 1, Ubud & 1.205 \\
\hline 8. & Sacred Rice & Jl. Cempaka. Kumbuh, Ubud & 525 \\
\hline 9. & Warung Pulau Kelapa & Jl. Raya Sanggingan, Ubud & 914 \\
\hline 10. & Semesta Warung & Monkey Forest Street No.9, Ubud & 268 \\
\hline
\end{tabular}

Sumber : TripAdvisor, 2019

Salah satu restaurant yang terdapat pada tabel tersebut adalah restaurant Sari Organik, Sari Organik merupakan salah satu restaurant di Ubud yang menyajikan makanan organik dan dianggap sebagai objek yang cocok untuk melakukan penelitian ini.

\section{METODE PENELITIAN}

Lokasi penelitian ini terletak di daerah Ubud, Kabupaten Gianyar, Bali tepatnya di restaurant Sari Organik Ubud yang beralamat di Jl. Subak Sok Wayah, Tjampuhan, Ubud, Gianyar, Kabupaten Gianyar, Bali 80571. Phone : (0361) 972087. Untuk sampai di Sari Organik wisatawan membutuhkan waktu sekitar 1 jam 22 menit dari badara I Gusti Ngurah Rai atau sekitar $37 \mathrm{~km}$. sedangkan dari kota Denpasar diperlukan waktu sekitar 58 menit berkendara atau sekitar 25 $\mathrm{km}$. 
Definisi Operasional Variabel

\begin{tabular}{|c|c|c|}
\hline Variabel & Sub Variabel & Indikator \\
\hline \multirow{4}{*}{$\begin{array}{l}\text { Motivasi } \\
\text { Konsumen } \\
\text { Engel. Blackwell, dan } \\
\text { Miniard (1994) }\end{array}$} & $\begin{array}{l}\text { Produk (X1) } \\
\text { (Kotler 2002) }\end{array}$ & $\begin{array}{l}\text { 1) Kualitas produk sesuai dengan yang } \\
\text { diinginkan } \\
\text { 2) Penampilan produk yang baik } \\
\text { 3) Variasi menu yang beragam } \\
\end{array}$ \\
\hline & $\begin{array}{l}\text { Harga }(X 2) \\
\text { (Marwan 1986) }\end{array}$ & $\begin{array}{l}\text { 4) Harga yang terjangkau } \\
\text { 5) Harga sesuai kualitas } \\
\text { 6) Harga bersaing }\end{array}$ \\
\hline & $\begin{array}{l}\text { Pelayanan }(X 3) \\
\text { (Sofjan 2002) }\end{array}$ & $\begin{array}{l}\text { 7) Pelayan yang cepat } \\
\text { 8) Pelayanan yang ramah }\end{array}$ \\
\hline & $\begin{array}{l}\text { Lokasi (X4) } \\
\text { (Engel, Blackwell, } \\
\text { dan Miniard 1994) }\end{array}$ & $\begin{array}{l}\text { 9) Lokasi yang strategis } \\
\text { 10) Lokasi memiliki pemandangan } \\
\text { yang indah }\end{array}$ \\
\hline
\end{tabular}

Sumber : Hasil modifikasi peneliti, 2019

Jenis data yang digunakan adalah data kualitatif dan data kuantitatif. Sumber data menggunakan data primer dan data sekunder. Teknik pengumpulan data dilakukan dengan observasi, wawancara tidak terstruktur, kuesioner, studi kepustakaan, dan dokumentasi. Teknik penentuan informan menggunakan teknik accidental sampling. Teknik pengambilan sampel ditentukan menggunakan rumus Slovin diperoleh sampel sejumlah 100 orang. Teknik analisis data menggunakan analisis deskriptif kualitatif dan analisis kuantitatif. Analisis deskriptif kualitatif digunakan untuk menggambarkan karakteristik responden dan deskripsi kuantitatif analisis yang menggunakan rumus dalam menganalisis masalah yang ditemukan di lokasi penelitian untuk meneliti faktor-faktor yang mempengaruhi motivasi konsumen memilih makanan organik di restaurant Sari Organik Ubud Bali, dimana data diperoleh dari penyebaran kuesioner menggunakan metode pengukuran skala likert kepada sejumlah sampel yang telah ditentukan. Menurut Sugiyono (2018 : 158) skala likert digunakan untuk mengukur sikap, pendapat, dan persepsi seseorang atau sekelompok orang tentang fenomena sosial. Dalam hal ini, skala likert digunakan untuk menganalisis faktor-faktor yang mempengaruhi motivasi konsumen memilih makanan organik di restaurant Sari Organik Ubud Bali. Selanjutnya untuk menganalisis tanggapan konsumen digunakan pengukuran skala likert sehingga jawaban-jawaban konsumen sesuai dengan variabel terhadap seluruh pertanyaan yang diajukan dengan pemberian skor, sebagai berikut.

1) Skor 5 (lima) untuk jawaban atau tanggapan yang sangat setuju

2) Skor 4 (empat) untuk jawaban atau tanggapan yang setuju

3) Skor 3 (tiga) untuk jawaban atau tanggapan yang cukup

4) Skor 2 (dua) untuk jawaban atau tanggapan yang tidak setuju

5) Skor 1 (satu) untuk jawaban atau tanggapan yang sangat tidak setuju

Untuk mengetahui intensitas sikap wisatawan, dibuat kategori sikap dengan mencari terlebih dahulu rentang nilainya dengan rumus dibawah ini:

$$
\begin{gathered}
\frac{\text { Skor tertinggi-skor terendah }}{\text { Jumlah kelas }}=\text { Rentang/interval } \\
\frac{5-1}{5}=0,8
\end{gathered}
$$

Berdasarkan rumus tersebut, berarti bahwa masing-masing kategori memiliki rentang nilai (interval) sebesar 0,8 . Hal ini dapat dilihat pada nilai rata-rata berikut:

1) 4,21 - 5,00: Termasuk kategori sangat setuju (SS)

2) 3,41-4,20: Termasuk kategori Setuju (S)

3) 2,61-3,40: Termasuk kategori Cukup (C)

4) 1,81-2,60: Termasuk Kategori tidak setuju (TS) 


\section{5) 1,00 - 1,80: Termasuk Kategori sangat tidak setuju (STS)}

Selanjutnya analisis deskriptif kuantitatif menggunakan uji validitas, uji reliabilitas, dan analisis faktor dengan melakukan korelasi indikator, ekstraksi faktor, rotasi faktor dan interprestasi faktor menggunakan bantuan aplikasi program SPSS 16 for Windows.

\section{HASIL DAN PEMBAHASAN}

Pemilik dari Sari Organik bernama Ibu Nila Wati, sebagai pemilik dan chef Sari Organik awalnya beliau tidak mengetahui apa itu organik, pada tahun 2002 Ibu Nila Wati hanya menanam dengan cara alami tanpa bahan-bahan kimia atau apapun sehingga tanaman tumbuh dengan alami. Menurutnya metode yang digunakan dalam menanam adalah yang nantinya menghasilkan sayuran yang baik untuk tubuh. Berawal dari keresahan karena para petani sekitar yang menggunakan bahan kimia untuk menanam maka sejak saat itulah Ibu Nila Wati dan tim Sari Organik mulai menanam berbagai tanaman tanpa menggunakan bahan kimia. Seiring berjalannya waktu Sari Organik pun menjadi contoh kepada para petani sekitar dan menunjukan bahwa organik pun bisa menjadi peluang usaha yang baik dan dikenal. Sari Organik yang dikenal juga dengan nama Warung Bodag Maliah yang artinya berasal dari bahasa bali, Bodag yang berarti keranjang dan Maliah yang berarti isi yang berlimpah sampai meluap, sehingga jika kedua kata tersebut digabungkan akan berarti keranjang dengan isi yang berlimpah, penggunaan nama ini dikarenakan, baik dalam hal menanam dan memasak, tempat ini menggunakan gaya lama berdasarkan metode tradisional. Sari Organik awalnya merupakan sebuah organisasi yang menciptakan tanaman organik dan mereka mendeskripsikan Sari Organik sebagai "Pusat Pertanian dan Pengolahan Makanan Beras dan Sayur Mayur Tanpa Kimia”. Hingga sekarang Sari Organik bekerjasama dengan beberapa petani lokal dalam mebududayakan tanaman-tanaman lokal disertai dengan sistem perdagangan yang adil dan setara.

\section{Karakteristik Responden}

Konsumen yang berkunjung ke Sari Organik memiliki karakteristik yang breagam. Pada penelitian ini karakteristik yang dimaksud adalah negara asal yang dikelompokan berdasarkan benua, latar belakang pendidikan, umur, jenis kelamin.

\section{Responden Berdasarkan Asal Benua}

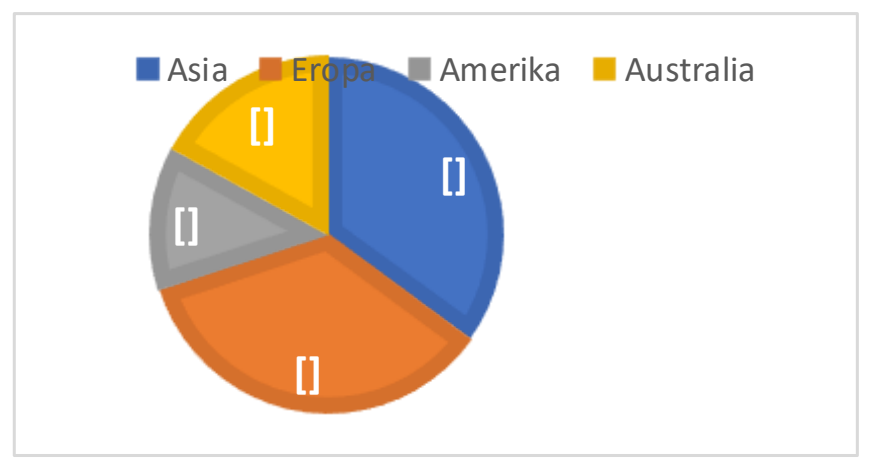

Sumber : Hasil olahan kuesioner, 2019

Gambar 4.1 Responden Berdasarkan Asal Benua

Dilihat dari negara asal yang telah di klasifikasikan berdasarkan benuanya konsumen yang berkunjung ke Sari Organik Ubud paling banyak berasal dari benua Eropa dan Asia yaitu masingmasing berjumlah sebanyak 35 orang atau 35\%, konsumen tebanyak kedua setelah Eropa dan Asia yaitu berasal dari benua Australia sebanyak 17 orang atau 17\%, dan jumlah konsumen yang paling sedikit dan yang terakhir merupakan kewarganegaraan Amerika yang berjumlah 13 orang atau $13 \%$. 


\section{Responden Berdasarkan Jenis Kelamin}

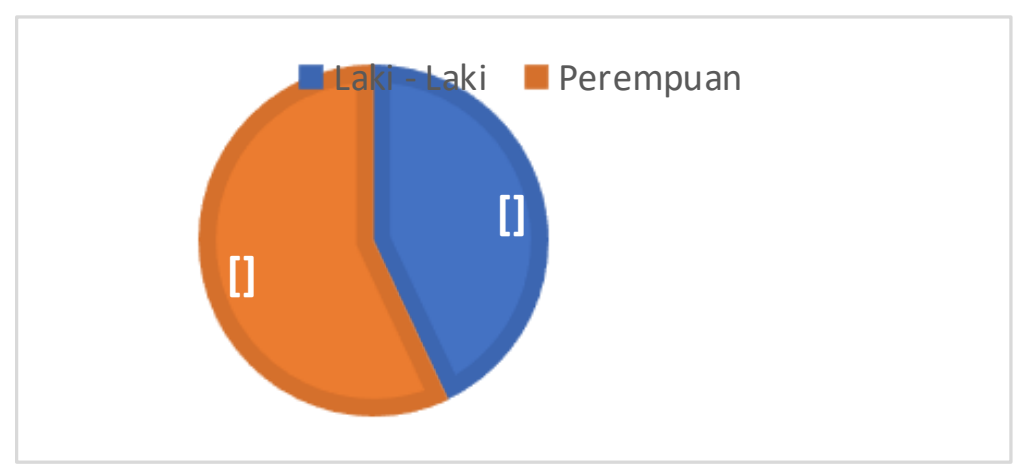

Sumber : Hasil olahan kuesioner, 2019

Gambar 4.2 Responden Berdasarkan Jenis Kelamin

Dari Gambar 4.2 dapat diketahui bahwa jumlah konsumen yang berkunjung dan melakukan pembelian makanan organik di Sari Organk Ubud lebih didominasi oleh perempuan dengan jumlah 57 orang yaitu 57\% sedangkan laki-laki berjumlah 43 orang yaitu $43 \%$.

\section{Responden Berdasarkan Rentang Usia}

Sumber : Hasil olahan kuesioner, 2019

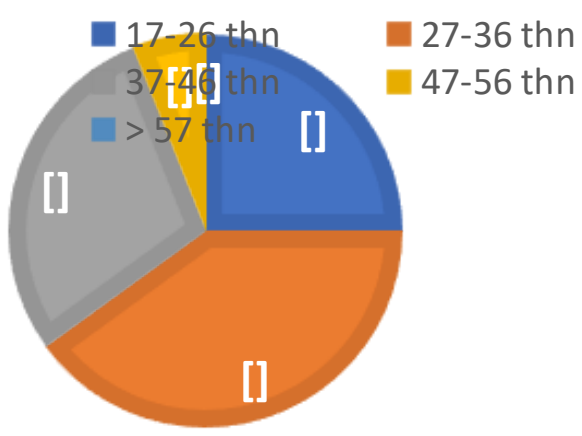

Gambar 4.3 Responden Berdasarkan Rentang Usia

Dari Gambar 4.3 dapat dideskripsikan bahwa rentang usia konsumen antara 17-26 tahun yang berkunjung ke Sari Organik terdapat sebanyak 25 orang atau 25\%, rentang umur 27-36 tahun sebanyak 40 orang atau 40\%, rentang usia 37-46 tahun sebanyak 29 orang atau $29 \%$ dan rentang usia 47-56 tahun sebanyak 6 orang atau 6\%, sedangkan tidak ada konsumen yang berumur 57 keatas, dari hal tersebut dikehui bahwa mayoritas konsumen yang berkunjung ke Sari Organik berentang umur 27-36 tahun. Hal tersebut juga dapat didukung dari hasil observasi peneliti saat berkunjung ke lokasi penelitian bahwa kebanyakan konsumen yang mengunjungi Sari Organik adalah pasangan yang sudah menikah dan banyak juga konsumen berkeluarga yang mengajak serta anak-anaknya untuk menikmati makanan organik. 


\section{Responden Berdasarkan Pendidikan Terakhir}

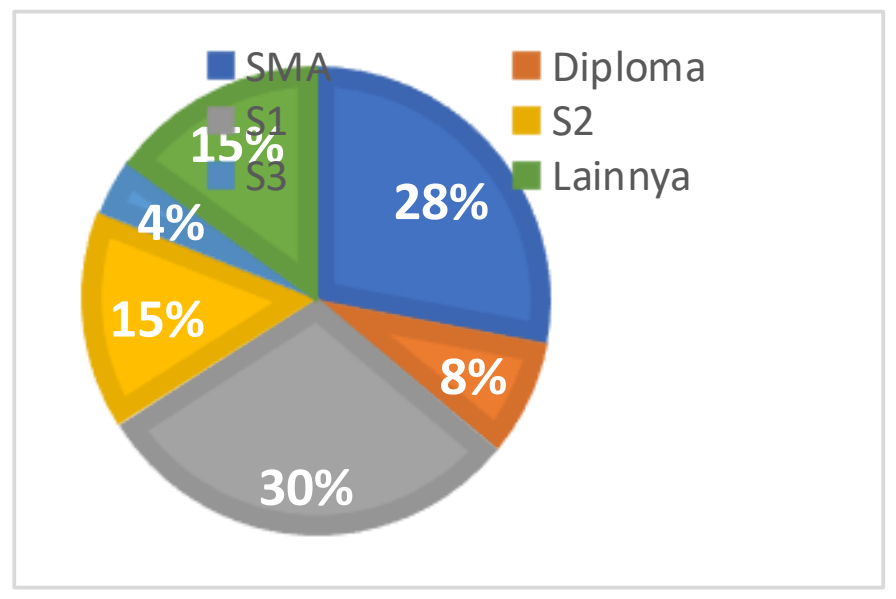

Sumber : Hasil olahan kuesioner, 2019

Gambar 4.4 Responden Berdasarkan Pendidikan Terakhir

Dilihat dari Gambar 4.4 dapat diketahui bahwa kebanyakan konsumen yang melakukan pembelian makanan organik di restaurant Sari Organik Ubud memiliki pendidikan terakhir Bachelor / S1, yaitu dengan jumlah sebanyak 30 orang atau 30\%. Selanjutnya yaitu high school / sekolah menengah yaitu 28 orang atau $28 \%$, master / S2 sebanyak 15 orang atau $15 \%$, diploma sebanyak 8 orang atau $8 \%$. Sedangkan terdapat 15 orang atau 15\% yang memiliki pendidikan terakhir yang berbeda dan juga tidak menyebutkannya.

\section{Responden Berdasarkan Banyaknya Kunjungan}

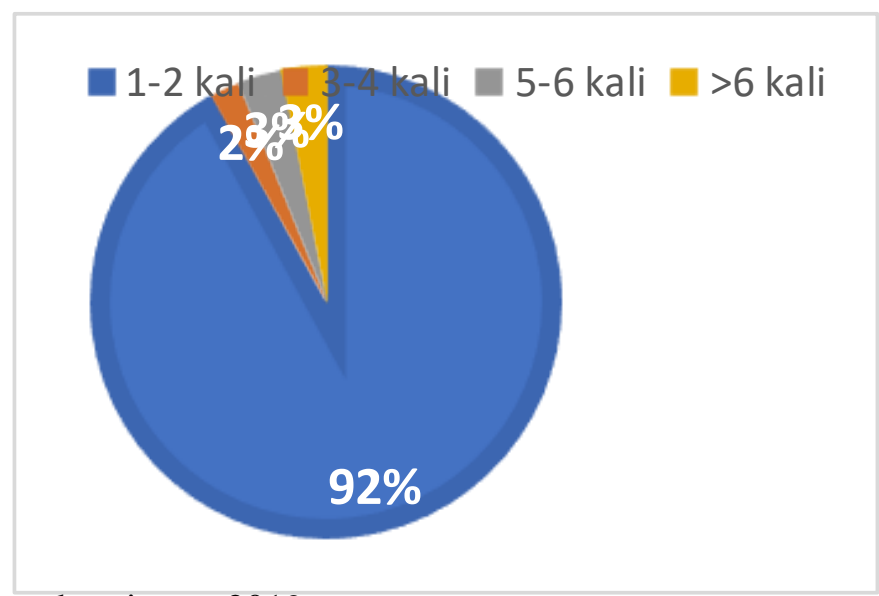

Sumber : Hasil olahan kuesioner, 2019

Gambar 4.6 Responden Berdasarkan Banyaknya Kunjungan

Dari data di Gambar 4.5 dapat diketahui bahwa mayoritas konsumen di restaurant Sari Organik yang mengunjungi restoran ini sebanyak 1-2 kali yaitu sebanyak 92 orang atau $92 \%$. Terdapat pula konsumen yang telah mengunjungi Sari Organik 5-6 kali bahkan lebih dengan jumlah masing-masing 3 orang atau 3\% dan juga terdapat 2 orang atau sebanyak $2 \%$ yang mengunjungi restaurant ini sebanyak 3-4 kali. 


\section{Responden Berdasarkan Sumber Informasi}

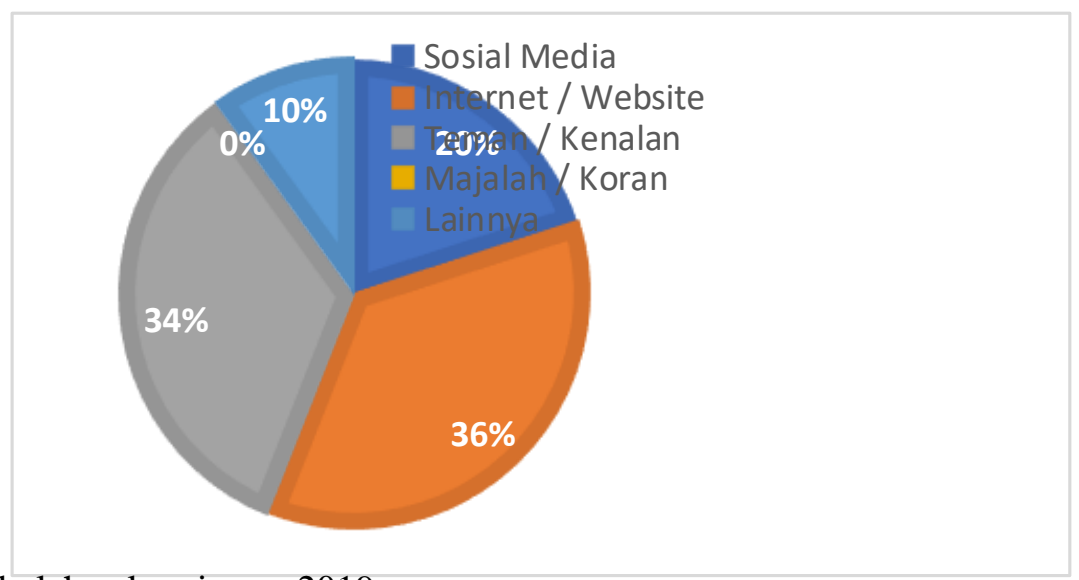

Sumber : Hasil olahan kuesioner, 2019

Gambar 4.6 Responden Berdasarkan Sumber Informasi

Dari data pada Gambar 4.6 diketahui bahwa mayoritas atau kebayakan konsemen yang berkunjung ke restaurant Sari Organik mengetahui informasi seputar Sari Organik dari internet / website, yaitu sebanyak 36 orang atau 36\%, selanjutnya sebanyak 34 orang atau $34 \%$ konsumen di Sari Organik mendapatkan informasi dari teman / kenalan, 20 orang atau sebanyak $20 \%$ konsumen mendapatkan informasi dari sosial media, 10 orang atau sebanyak $10 \%$ konsumen mendapatkan sumber informasi dari sumber lainnya, seperti travel agent, hotel, mencarian di google maps dan lainnya.

Secara keseluruhan responden yang berkunjung ke restaurant Sari Organik Ubud mayoritas konsumen mancanegara berasal negara-negara di benua Eropa dengan rentang usia 2736 tahun, berjenis kelamin wanita dan menyenyam pendidikan hingga tingkat sarjana atau S1.

\section{Motivasi Memilih Makanan Organik}

Tabel 4.1 Rekapitulasi Motivasi Memilih Makanan Organik

\begin{tabular}{|c|c|c|c|c|}
\hline \multirow{2}{*}{ No } & \multicolumn{5}{|c|}{ Indikator } \\
\cline { 2 - 5 } & Produk & Harga & Pelayanan & Lokasi \\
\hline 1. & 313 & 266 & 301 & 303 \\
\hline 2. & 295 & 327 & 314 & 303 \\
\hline 3. & 273 & 317 & - & - \\
\hline Total & 881 & 910 & 615 & 606 \\
\hline Rata-rata & 293,6 & 303,3 & 307,5 & 303 \\
\hline Kategori & & \multicolumn{5}{|c|}{ Cukup } \\
\hline
\end{tabular}

Sumber: Hasil kuesioner penelitian, 2019

Berdasarkan Tabel 4.1 motivasi konsumen terhadap keseluruhan variabel memilih makanan organik di restaurant Sari Organik Ubud Bali dapat dilihat bahwa harga memiliki nilai tertinggi sebesar 910 yang berarti cukup, selanjutnya produk memiliki nilai 881, pelayanan memiliki nilai 615, lokasi memiliki nilai 606 yang menyatakan cukup. 


\section{Uji Validitas}

Sebelum melakukan penyebaran kuesioner kepada 100 responden, Uji validitas dilakukan pada setiap instrument untuk mengetahui tingkat validitas dari instrument tersebut. Hasil output pengujian validitas pada penelitian ini menggunakan teknik analisis reliability pada software SPS S 16.0. Adapun hasil perhitungan validitas dirangkum melaui Tabel 4.2

Tabel 4.2 Hasil Output Pengujian Validitas

\begin{tabular}{|c|c|c|c|c|c|}
\hline No & Indikator & Item & Nilai & $\mathrm{R}_{\text {hitung }}(\mathrm{DF}=\mathrm{N}-2)$ & Status Validitas \\
\hline 1. & $\begin{array}{c}\text { Kualitas produk sesuai } \\
\text { dengan yang diinginkan }\end{array}$ & $\mathrm{X} 1.1$ &, 673 & 0,1966 & Valid \\
\hline 2. & Penampilan produk yang baik & $\mathrm{X} 1.2$ &, 580 & 0,1966 & Valid \\
\hline 3. & Variasi menu yang beragam & $\mathrm{X} 1.3$ &, 502 & 0,1966 & Valid \\
\hline 4. & Harga yang terjangkau & $\mathrm{X} 2.1$ &, 527 & 0,1966 & Valid \\
\hline 5. & Harga sesuai kualitas & $\mathrm{X} 2.2$ &, 589 & 0,1966 & Valid \\
\hline 6. & Harga bersaing & $\mathrm{X} 2.3$ &, 714 & 0,1966 & Valid \\
\hline 7. & Pelayanan yang cepat & $\mathrm{X} 3.1$ &, 649 & 0,1966 & Valid \\
\hline 8. & Pelayanan yang ramah & $\mathrm{X} 3.2$ &, 500 & 0,1966 & Valid \\
\hline 9. & Lokasi yang strategis & $\mathrm{X} 4.1$ &, 647 & 0,1966 & Valid \\
\hline 10. & $\begin{array}{c}\text { Lokasi memliki } \\
\text { pemandangan yang indah }\end{array}$ & $\mathrm{X} 4.2$ &, 675 & 0,1966 & Valid \\
\hline
\end{tabular}

Sumber: Hasil kuesioner penelitian, 2019

Berdasarkan Tabel 4.2 terdapat 10 sub indiakator. Dari data tersebut menunjukkan keseluruan hasil uji validitas diatas 0,1966. Maka dapat disimpulkan bahwa keseluruhan instrument pada 10 indikator tersebut valid.

\section{Uji Reliabilitas}

Uji reliabilitas dilakukan untuk mengetahui konsistensi alat ukur. Hasil output pengujian relliabilitas dengan menggunakan teknik analisis reliability pada software SPSS 16 dirangkum sebagai berikut:

Tabel 4.3 Hasil Output Uji Reliability

\begin{tabular}{|c|c|}
\hline \multicolumn{2}{|c|}{ Reliability Statistics } \\
\hline $\begin{array}{l}\text { Cronbach's } \\
\text { Alpha }\end{array}$ & $\mathrm{N}$ of Items \\
\hline .80 & 10 \\
\hline
\end{tabular}

Sumber : Hasil Pengolahan Data SPSS 16, 2019

Berdasarkan Tabel 4.3 ke 10 indikator tersebut diuji melalui metode Cronbach's alpha untuk mengukur tingkat reliabilitas seluruh instrument. Keseluruhan indikator tersebut dinyatakan reliabel karena nilai cronbach alpha diatas 0,6.

Uji validitas dan reliabililtas dengan pengelolaan program SPSS 16 dalam penelitian ini dinyatakan valid dan reliabel. Oleh karena itu, alat ukur dalam penelitian ini dinyatakan konsisten jika dilakukan pengukuran kembali. 


\section{Analisis Faktor}

Hasil dari perhitungan analisis faktor adalah sebagai berikut:

\section{Menghitung Kolerasi Indikator}

Pada matrix korelasi akan didefinisikan indikator mana saja saling berhubungan dari 10 indikator yang diteliti. Untuk menguji apakah indikator yang diteliti saling berhubunngan maka dilakukan Uji Barllet Test of Sphericity, Uji Kaisar Mayer Olkin (KMO), Uji Measure Of Sampling Asequancy (MSA) dan uji Communalities. Berdasarkan keempat uji tersebut dapat dilihat pada Tabel 4.4 dibawah ini:

Tabel 4.4 KMO and Bartlett's Test

KMO and Bartlett's Test

\begin{tabular}{|ll|r|}
\hline Kaiser-Meyer-Olkin Measure of Sampling Adequacy. & .758 \\
Bartlett's Test of & Approx. Chi-Square & 319.630 \\
Sphericity & Df & 45 \\
& Sig. & .000 \\
\hline
\end{tabular}

Sumber : Hasil Pengolahan Data SPSS 16, 2019

Tabel 4.4 menunjukkan nilai Kaise Mayer Olkin Measure of Sampling (KMO) menunjukkan angka 0,758 hal ini berarti peryaratan KMO memenuhi persyaratan minimal yang melebihi nilai 0,5 yang berarti dindikator sudah layak di faktorkan.

1. Uji Bartlett's Test of Sphericity

Uji Bartlett's test of sphericity adalah salah satu uji statistik untuk menentukan signifikan menyeluruh dari semua korelasi di dalam matrix korelasi. Dalam hal ini nilai uji Bartlett's tesf of sphericity diperoleh dengan nilai sebesar 319.630 dengan nilai signifikan 0,000. Ini menujukkan bahwa peluang terjadinya kesalahan untuk indikator tidak independen sebesar $0 \%$ dengan demikian indikator memiliki korelasi.

\section{Uji Measure of Sampling Asequency (MSA)}

Pesyaratan uji KMO telah terpenuhi maka perlu diamati ke 10 indikator tersebut dengan Uji Measure Of Sampling Asequancy (MSA) yakni dengan mengukur derajat korelasi antara indikator. Indikator-indikator yang layak untuk di proses lebih lanjut dan mana yang harus dikeluarkan. Apabila Uji Measure Of Sampling Asequancy (MSA) dari masing-masing indikator > 0,5 maka dapat di proses lebih lanjut, maka hal ini dapat dilihat pada Tabel Image Corelation dengan angka yang membentuk tanda "a". Seperti pada Tabel 4.5 dibawah ini:

Tabel 4.5 Nilai Measure of Sampling Asequancy (MSA) dengan 10 Sub Indikator Pada Anti Image Matrices

\begin{tabular}{|c|l|c|}
\hline No. & \multicolumn{1}{|c|}{ Indikator } & Nilai MSA \\
\hline 1. & Kualitas produk sesuai dengan yang diinginkan & $0,781^{\mathrm{a}}$ \\
\hline 2. & Penampilan produk yang baik & $0,750^{\mathrm{a}}$ \\
\hline 3. & Variasi menu yang beragam & $0,754^{\mathrm{a}}$ \\
\hline 4. & Harga yang terjangkau & $0,737^{\mathrm{a}}$ \\
\hline 5. & Harga sesuai kualitas & $0,788^{\mathrm{a}}$ \\
\hline 6. & Harga bersaing & $0,755^{\mathrm{a}}$ \\
\hline 7. & Pelayanan yang cepat & $0,800^{\mathrm{a}}$ \\
\hline 8. & Pelayanan yang ramah & $0,568^{\mathrm{a}}$ \\
\hline 9. & Lokasi yang strategis & $0,754^{\mathrm{a}}$ \\
\hline 10. & Lokasi yang memiliki pemandangan yang indah & $0,843^{\mathrm{a}}$ \\
\hline
\end{tabular}

Sumber : Hasil Pengolahan Data SPSS 16, 2019 
Berdasarkan Tabel 4.5 dapat dilihat bahwa 10 indikator yang digunakan tidak ada yang memperoleh nilai MSA (measure of sampling aquency) $<0,5$ yang artinya syarat-syarat MSA (measure of sampling aquency) sudah dapat terpenuhi dan proses analisa faktor dapat dilanjutkan.

\section{Ekstraksi Faktor}

Nilai eigenvalues $>1$ merupakan nilai yang dipilih, semakin besar nilai maka seamakin besar faktor tersebut mewakili sekelompok variabel. Faktor yang terbentuk dari hasil proses pengolahan data sebelumnya dapat dilihat pada Tabel Total Variance Explaind, tabel ini akan menunjukkan besarnya persentase keragaman total yang mampu diterangkan oleh keragaman faktor-faktor yang terbentuk, pada tabel ini terdapat eigenvalues dari tiap-tiap faktor yang terbentuk. Adapun nilai tersebut dapat dilihat pada Tabel 4.6.

Tabel 4.6 Total Variance Explained

Total Variance Explained

\begin{tabular}{|c|c|c|c|c|c|c|c|c|c|}
\hline \multirow{2}{*}{$\begin{array}{c}\text { Comp } \\
\text { onent }\end{array}$} & \multicolumn{3}{|c|}{ Tnitial Eigenvalues } & \multicolumn{3}{c|}{$\begin{array}{c}\text { Extraction Sums of Squared } \\
\text { Loadings }\end{array}$} & \multicolumn{3}{|c|}{ Rotation Sums of Squared } \\
\cline { 2 - 9 } & $\begin{array}{c}\text { \% of } \\
\text { Variance }\end{array}$ & $\begin{array}{c}\text { Cumulatings } \\
\text { ve \% }\end{array}$ & Total & $\begin{array}{c}\text { \% of } \\
\text { Variance }\end{array}$ & $\begin{array}{c}\text { Cumulati } \\
\text { ve \% }\end{array}$ & Total & $\begin{array}{c}\text { \% of } \\
\text { Variance }\end{array}$ & $\begin{array}{c}\text { Cumulati } \\
\text { ve \% }\end{array}$ \\
\hline 1 & 3.734 & 37.338 & 37.338 & 3.734 & 37.338 & 37.338 & 2.969 & 29.687 & 29.687 \\
2 & 1.793 & 17.932 & 55.270 & 1.793 & 17.932 & 55.270 & 2.558 & 25.583 & 55.270 \\
3 & .974 & 9.737 & 65.007 & & & & & & \\
4 & .740 & 7.401 & 72.407 & & & & & & \\
5 & .682 & 6.819 & 79.226 & & & & & & \\
6 & .551 & 5.514 & 84.741 & & & & & & \\
7 & .505 & 5.046 & 89.787 & & & & & & \\
8 & .419 & 4.185 & 93.972 & & & & & & \\
9 & .335 & 3.348 & 97.321 & & & & & & \\
10 & .268 & 2.679 & 100.000 & & & & & & \\
\hline
\end{tabular}

Extraction Method: Principal

Component Analysis.

Sumber : Hasil Pengolahan Data SPSS 16, 2019

Berdasarkan Tabel 4.6, menunjukkan masing-masing variabel yang dianalisis. Dalam penelitian ini ada 10 indikator yang tersisa berarti ada 10 Component yang dianalisis. Berdasarkan Initial Eigenvalues maka ada dua faktor yang dapat terbentuk dari 10 indikator yang dianalisis. Dimana syarat untuk menjadi sebuah faktor yaitu nilai Eigenvalues harus $>1$. Nilai komponen 1 sebesar 3,734 atau lebih dari 1 maka menjadi faktor 1 dan mampu menjelaskan 37,338\% variansi. Sedangkan nilai Eigenvalues komponen 2 sebesar 1,793 atau >1 maka menjadi faktor 2 dan mampu menjelaskan 17,932\% variansi. Jika faktor 1 dan 2 dijumlahkan maka mampu menjelaskan 55,270\% variansi. Nilai komponen 3 dan seterusnya sampai komponen 10 tidak dihitung sebab nilai Eigenvalues $<1$ maka tidak menjadi sebuah faktor. Adapun scree plot pada eigenvalue dapat dilihat pada Gambar grafik 4.4: 


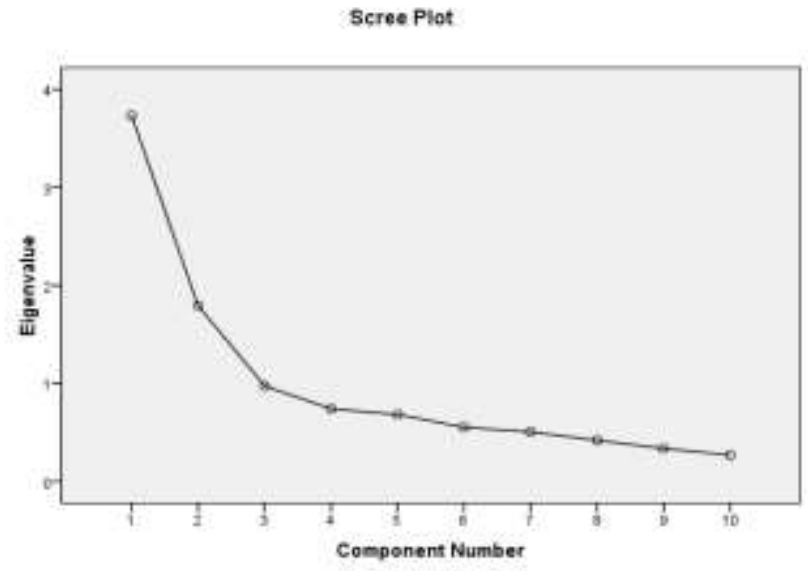

Sumber: Hasil kuesioner penelitian, 2019.

Gambar 4.7 Scree Plot

Berdasarkan Gambar 4.7 ini juga menunjukkan jumlah faktor yang terbentuk, yaitu dengan melihat titik komponen yang memiliki nilai Eigenvalues $>1$ maka dapat diartikan bahwa ada 2 faktor yang terbentuk.

Pada Tabel 4.7 berikut ini adalah menentukan item-item yang dominan pada setiap komponen yang terbentuk. Hal ini dapat dilihat dari komponen dari tabel Component Matrix yang menunjukkan distribusi item penelitian kedua faktor yang terbentuk.

Tabel 4.7 Component Matrix ${ }^{\mathrm{a}}$

Component Matrix ${ }^{\mathrm{a}}$

\begin{tabular}{|c|c|c|}
\hline \multirow{2}{*}{} & \multicolumn{2}{|c|}{ Component } \\
\cline { 2 - 3 } & 1 & 2 \\
\hline x1.1 & .682 & .379 \\
x1.2 & .591 & .482 \\
x1.3 & .491 & .611 \\
x2.1 & .503 & .559 \\
x2.2 & .583 & -.568 \\
x2.3 & .730 & -.195 \\
x3.1 & .654 & -.368 \\
x3.2 & .474 & -.372 \\
x4.1 & .641 & -.031 \\
x4.2 & .701 & -.308 \\
\hline
\end{tabular}

Extraction Method: Principal

Component Analysis.

a. 2 components extracted.

Sumber: Hasil kuesioner penelitian, 2019

Agar mudah menginterprestasikan kedua faktor tersebut dan agar mendapatkan struktur faktor yang lebih sederhana harus dilakukan rotasi faktor. 


\section{Rotasi Faktor}

Berikut adalah Tabel Rotated Component Matrix dapat dilihat pada Tabel 4.8.

Tabel 4.8 Rotated Component Matrix ${ }^{\mathrm{a}}$

Rotated Component Matrix ${ }^{\mathrm{a}}$
\begin{tabular}{|c|c|c|}
\hline \multirow{2}{*}{} & \multicolumn{2}{|c|}{ Component } \\
\cline { 2 - 3 } & 1 & 2 \\
\hline $\mathrm{x} 1.1$ & .293 & .724 \\
$\mathrm{x} 1.2$ & .157 & .747 \\
$\mathrm{x} 1.3$ & -.002 & .784 \\
$\mathrm{x} 2.1$ & .040 & .751 \\
$\mathrm{x} 2.2$ & .810 & -.076 \\
$\mathrm{x} 2.3$ & .690 & .306 \\
$\mathrm{x} 3.1$ & .740 & .124 \\
$\mathrm{x} 3.2$ & .602 & .008 \\
x4.1 & .518 & .378 \\
x4.2 & .739 & .200 \\
\hline
\end{tabular}

Extraction Method: Principal

Component Analysis.

Rotation Method: Varimax

with Kaiser Normalization.

a. Rotation converged in 3

iterations.

Sumber: Hasil kuesioner penelitian, 2019

Hasil dari rotasi faktor memberikan informasi bahwa terdapat 2 buah faktor dari 10 indikator yang telah diolah. Penelitian ini menggunakan batasan bobot faktor yang lebih tinggi dari 0,50 dengan pertimbangan nilai korelasi pada batasan ini menunjukan tingkat hubungan yang cukup kuat antara variabel indikator terhadap faktor pembentuknya. Adapun dari rotasi tersebut adalah sebagai berikut:

1. Faktor pertama terdiri dari indikator-indikator X2.2, X2.3, X3.1, X3.2, X4.1, X4.2 Berdasarkan hasil yang diperoleh pada Tabel 4.12 , indikator X2.2 merupakan indikator yang memiliki nilai skor terbesar yaitu sebesar 0,810 .

2. Faktor kedua terdiri dari indikator-indikator X1.1, X1.2, X1.3, X2.1 Berdasarkan hasil yang diperoleh pada Tabel 4.12, indikator X1.3 merupakan indikator yang memiliki nilai skor variabel terbesar yaitu sebesar 0,784 .

4.9 .

Untuk lebih jelasnya pengelompokkan variabel ke dalam 2 faktor dapat dilihat pada Tabel

Tabel 4.9 Indentifikasi Hasil Rotasi Faktor-Faktor Motivasi Konsumen Memilih Makanan Organik di Restaurant Sari Organik Ubud Bali

\begin{tabular}{|c|c|c|c|}
\hline Faktor & Sub Indikator & Loading Faktor & Jumlah/Variabel \\
\hline \multirow{7}{*}{1.} & $\begin{array}{c}\text { Harga sesuai kualitas } \\
\text { (X2.2) }\end{array}$ & 0,810 & $\begin{array}{c}1,500 \\
\text { (Harga) }\end{array}$ \\
\cline { 2 - 3 } & Harga bersaing (X2.3) & 0,690 & \multirow{1}{1}{$\begin{array}{c}1,342 \\
\text { (Pelayanan) }\end{array}$} \\
\cline { 2 - 3 } & $\begin{array}{c}\text { Pelayanan yang cepat } \\
\text { (X3.1) }\end{array}$ & 0,740 & \multirow{2}{*}{0,602} \\
\cline { 2 - 3 } & $\begin{array}{c}\text { Pelayanan yang ramah } \\
\text { (X3.2) }\end{array}$ & & \\
\hline
\end{tabular}




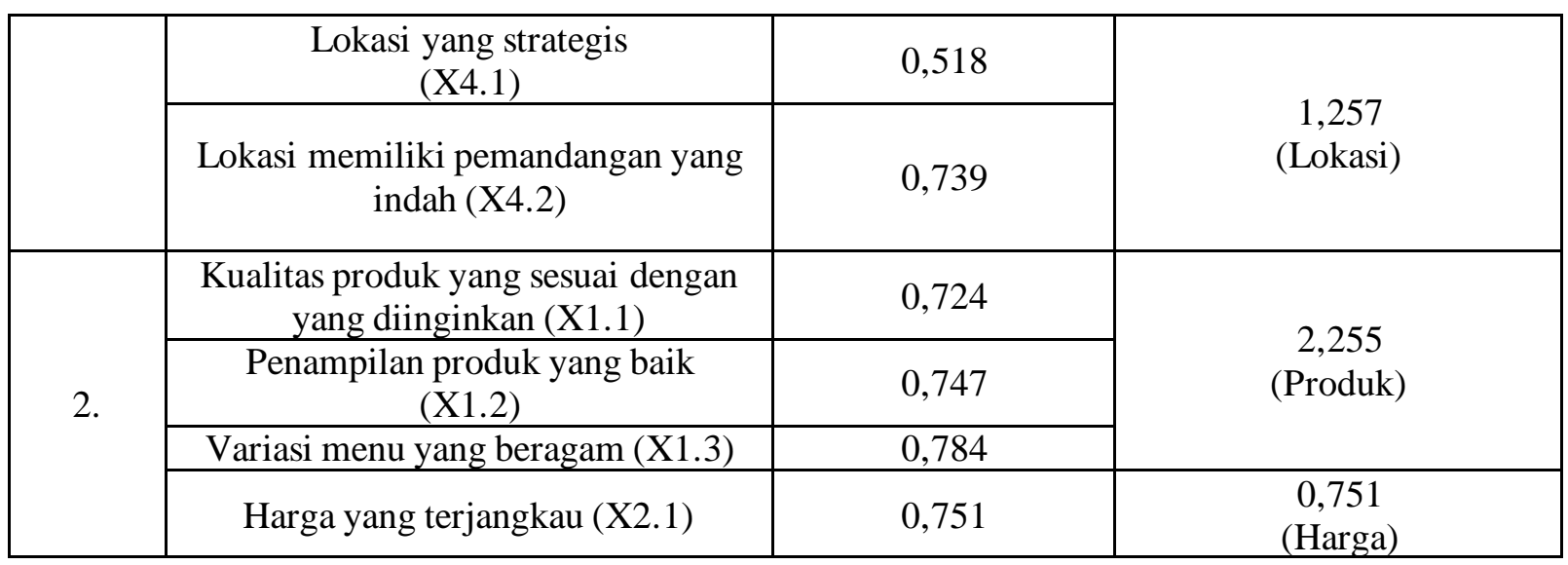

Sumber: Hasil kuesioner penelitian, 2019

Berdasarkan Tabel 4.9 diperoleh dua faktor yang merupakan hasil reduksi dari seluruh indikator-indikator yang ada yang ada, tahapan berikutnya adalah tahapan pemberian nama (pemberian identitas) pada kedua faktor tersebut.

1. Faktor pertama yang terdiri dari variabel-variabel X2.2, X2.3, X3.1, X3.2, X4.1 dan X4.2 diberi nama faktor Harga dimana indikator-indikator yang terdapat di dalam nya lebih menekankan terhadap variabel Harga dengan total bobot indikator adalah 1,500.

2. Faktor pertama yang terdiri dari variabel-variabel X1.1, X1.2, X1.3, dan X2.1 diberi nama faktor Produk dimana indikator-indikator yang terdapat di dalamnya lebih menekankan terhadap variabel Produk dengan total bobot indikator adalah 2,255.

\section{Interprestasi faktor}

Hasil rotasi faktor diperoleh dua faktor utama yang diyakini mampu mempresentasikan seluruh indikator yang terkandung pada masing-masing faktor tersebut. Dari semua indikator dimasukkan menjadi dua faktor yang dapat menjelaskan $55,270 \%$ dari total varian yang ada. Adapun faktor tersebut terdiri dari:

1. Faktor pertama memiliki 6 bobot faktor yang signifikan. Sub indikator dengan bob ot tertinggi pada faktor ini adalah indikator X2.2 (harga sesuai kualitas) dan X2.3 (harga bersaing) memiliki total korelasi sebesar 1,500. Faktor ini dapat didefinisikan seb ag ai faktor "Harga" dan dianggap mampu mewakili seluruh indikator.

2. Faktor kedua memiliki 4 bobot faktor yang signifikan. Sub indikator dengan bobot tertinggi pada faktor ini adalah indikator X1.1 (kualitas produk yang sesuai dengan yang diinginkan), X1.2 (penampilan produk yang baik), dan X1.3 (variasi menu yang beragam) memiliki total korelasi sebesar 2,255. Faktor ini dapat didefinisikan sebagai faktor "Produk" dan dianggap mampu mewakili seluruh indikator.

\section{Faktor yang Mempengaruhi dan Dominan Menentukan Motivasi Konsumen Memilih Makanan Organik di Restaurant Sari Organik Ubud Bali}

Berdasarkan hasil interprestasi faktor dapat diketahui terdapat 2 faktor yang mempengaruhi motivasi konsumen memilih makanan organik di restaurant Sari Organik Ubud Bali yaitu faktor harga dengan indikator harga sesuai kualitas dan harga bersaing dengan total korelasi sebesar 1,500. Selanjutnya adalah faktor produk dengan indikator kualitas produk yang sesuai dengan yang diinginkan, penampilan produk yang baik dan variasi menu yang beragam dengan total korelasi sebesar 2,255.

Berdasarkan hasil rotasi diperoleh faktor yang memiliki nilai total korelasi indikator yaitu faktor produk dengan nilai sebesar 2,255 yang memiliki 4 sub indikator meliputi: (1) kualitas produk sesuai dengan yang diinginkan, (2) penampulan produk yang baik, (3) variasi menu yang 
beragam, dan (4) harga yang terjangkau. Setelah dilakukan rotasi dan ekstraksi faktor, dapat disimpulkan dari 10 indikator yang digunakan untuk mengetahui faktor yang paling dominan yang mempengaruhi motivasi konsumen memilih makanan organik di restaurant Sari Organik Ubud Bali adalah Faktor Produk dengan nilai total korelasi indikator sebesar 2,255.

\section{KESIMPULAN}

Dari hasil analisis faktor tersisa 10 indikator dari 10 indikator yang di analisis. Dari hasil analisis faktor tersebut terdapat 2 faktor yang terbentuk yang dapat menjelaskan 55,270\% dari total varians yang ada. Dari kedua faktor yang terbentuk adalah faktor pertama yaitu Harga dan faktor yang kedua yaitu Produk.

Faktor dominan yang mempengaruhi motivasi konsumen memilih makanan organik di restaurant Sari Organik Ubud Bali adalah faktor Produk dengan total korelasi 2,255 melebihi faktor Harga yaitu 1,500. Jadi dapat disimpulkan bahwa faktor Produk dapat mempengaruhi konsumen dalam memilih makanan organik.

\section{Ucapan terima kasih}

Penulis mengucapkan terimakasih kepada Ibu Dra. Anak Agung Putri Sri, M.Si dan Bapak I Nyoman Tri Sutaguna, S.ST.Par.,M.Par. serta semua pihak yang telah bersedia memberikan bimbingan serta arahan dari laporan akhir hingga penulisan jurnal ilmiah. Penulis juga ingin mengucapkan terimakasih kepada Bapak dan Ibu dosen serta staff tata usaha Fakultas Pariwisata Universitas Udayana yang telah membantu penulis dalam hal administrasi. Tidak lupa terimakasih juga untuk orang tua, keluarga dan sahabat seperjuanagan Diploma IV Pariwisata angkatan 2015 yang telah mendukung dan memberikan motivasi kepada penulis.

\section{DAFTAR PUSTAKA}

Arifin, Bustanul. 2005. Pembangunan Pertanian: Paradigma Kebijakan dan Strategi Revitalisasi. Jakarta: PT. Grasindo.

Arikunto, S. 2002. Metodologi Penelitian Suatu Pendekatan Proposal. Jakarta: PT. Rineka Cipta.

Assauri, Sofjan. 2002. Manajemen Pemasaran : Dasar Konsep dan Strategi. Jakarta: Raja Grafindo Persada.

A.W Marsum. 2005. Restoran dan Segala Permasalahannya edisi IV. Yogyakarta:Andi.

Badan Pusat Statistik Provinsi Bali. https://bali.bps.go.id/press releasemji/2020/01/02/717324/kunjungan-wisatawan-ke-bali-menurutbulan-1982-2018 html. Diakses pada 2 Oktober 2019.

Engel, Blackwell, dan Miniard. 1994. Perilaku Konsumen. Jakarta: Binarupa Aksara.

Goldman, B.J and Clancy, K.C. 1991. A survey of organic produce purchase and related attitudes of food cooperative shoppers. American Journal of Alternative Agriculture, Vol. 6, 89-95. Diakses pada 5 Oktober 2019

Ghozali, Imam. 2005. Aplikasi Analisis Multivariate dengan SPSS. Semarang: Badan Penerbit UNDIP.

Hasibuan, S. P. Melayu. 2009, Menejemen: Dasar, Pengertian, dan Masalah, Edisi Revisi. Jakarta: Bumi Aksara.

Hill, H. and Lyncchehaun, F. 2002. Organic milk: attitudes and consumption pattern. British Food Journal, Vol. 104 (7), 526-542. Diakses pada 5 Oktober 2019

Hutchins, R.K. and Greenhalgh, L.A. 1995. Organic confusion: sustaining competitive advantage. Nutrition \& Food Science Journal, Vol. 95 (6), 11-14. Diakses pada 5 Oktober 2019

Ivancevich, M., John. 2006. Perilaku dan Menejemen Organisasi, Edisi Ketujuh. Jakarta: Erlangga.

Kusumaningrum, Dian. 2009. Persepsi Wisatawan Terhadap Daya Tarik Wisata. Yogyakarta: Kajian.

Lea, E. and Wersley, T. 2005. Australians organic food beliefs, demographics and values. British Food Journal, Vol. 11, 855-869. Diakses pada 10 Oktober 2019 
Maharani, Nina. 2014. Telaah Penelitian Sebelumnya. Proses Pengambilan Keputusan Pembelian Konsumen Terhadap Produk Iphone di Bandung. From https://online journal. unja.ac. id/. Diakses pada 2 Oktober 2019

Marpaung, Happy., Herman Bahar. 2000. Pengantar Pariwisata. Bandung: Alfabeta. 2002. Pengetahuan Kepariwisataan Edisi Revisi, Bandung: Penerbit Alfabeta.

Meolong, L. J. 2006. Metodologi Penelitan Kualitatif. Bandung: PT. Remaja Rosdakarya.

Mulyadi, A. J. 2012. Kepariwisataan dan Perjalanan. Jakarta: Raja Grafindo Persada.

Mulyasa. E. 2003, Kurikulum Berbasis Kompetensi: Konsep, Karakteristik dan Implementasi. Bandung: Remaja Rosda Karya.

O'Donovan, P. and McCarthy, M. 2002. Irish consumer preference for organic meat. British Food Journal, Vol. 103 (3), 353-370. Diakses pada 5 Oktober 2019

Philip, Kotler. 2002. Manajemen Pemasaran, Jakarta: Prenhallindo

Pranasari, M.E. 2007. Perdagangan produk pertanian organik. Kompas Cyber Media.fromhttp://ww2.kompas.com/kompascetak/0411/08/ilpeng/1370325.htm. Diakses pada 29 November 2019

Raf, Mulyadi. 2012. Telaah Penelitian Sebelumnya. Pengaruh Faktor-Faktor Memotivasi Konsumen Berbelanja Terhadap Keputusan Konsumen Berbelanja Di Pasar Modern Kota Jambi. ISSN : 2302-4682. Vol 1 no. 1. From https://online-journal.unja.ac.id/ Diakses pada 1 Oktober 2019

Rivai, Veithzal. 2006. Menejemen Sumber Daya Manusia untuk Perusahaan, dari Teori ke Praktik, Edisi Pertama. Jakarta: Penerbit PT. Raja Grafindo Persada

Sangadji, E. M., Sopiah. 2013. Perilaku Konsumen: Pendekatan Praktis Disertai: Himpunan Jurnal Penelitian. Yogyakarta: Penerbit Andi.

Saputra, Rico. 2013. Telaah Penelitian Sebelumnya. Analisa Pengaruh Motivasi, Persepsi, Sikap Konsumen Terhadap Keputusan Pembelian Mobil Daihatsu Xenia di Sidoarjo. Jurnal Menejemen Pemasaran Vol 1 no. 1, 1-12. Diakses pada 3 Oktober 2019.

Schiffman, \& Kanuk. 2000. Consumer Behavior. Fifth Edition. New Jersey: Prentice Hall Inc.

Sigit, Soehardi. 2002. Pemasaran Praktis, edisi ketiga, Yogyakarta: STIE YKPN.

Soekresno. 2000. Manajemen Food and Baverage edisi ke II. Jakarta: PT. Gramedia Pustaka Utama.

Steven, R. 2007. Why healthy lunch, from http://www.heathylunchforyou. Diakses pada 15 Desember 2019.

Sugeng, H., 2007. Indonesia berpotensi jadi produsen tanaman organic dunia Antara News, http://www.antara.co .id/print/?i=1190369888. Diakses pada 23 September 2019.

Sugiarto, Hendratomo, dkk. 2015. Metodologi Penelitian Hospitaliti \& Pariwisata. Tangerang: Matana Publishing.

Sugiono. 2014. Metode Penelitian Kuantitatif Kualitatifdan R\&D. Bandung: Penerbit Alfabeta 2015. Statistika untuk Penelitian. Cetakan ke-26, Bandung: Penerbit Alfabeta.

Sujarweni, V. W., 2014. Metodologi Penelitian Lengkap, Praktis, dan Mudah Dipahami. Yogyakarta: Pustaka Baru Press.

Suwena, I Ketut, Widyatmaja, I Gusti Ngurah. 2010. Pengetahuan Dasar Ilmu Pariwisata, Denpasar: Udayana University Press.

Thio, Sienny. 2008. Telaah Penelitian Sebelumnya. Persepsi Konsumen Terhadap Makanan Organik di Surabaya. Universitas Kristen Petra. From https:// online-journal.unja.ac.id/ Diakses pada 3 Oktober 2019.

Widiastuti, S. 2004. Berita Pertanian Organik. Go Organik 2010 http:// www.goorganik2010 /beritapertanian/91887/organic. Diakses pada 1 Desember 2019.

Winardi. 2007. Motivasi dan Pemotivasian dalam Menejemen. Jakarta: Raja Grafindo Persada. 